\title{
PENGARUH MULTIMEDIA PEMBELAJARAN DAN KECERDASAN MUSIKAL TERHADAP HASIL BELAJAR PIANO MAHASISWA JURUSAN PENDIDIKAN SENI MUSIK
}

\author{
Deslina Simamora ${ }^{1}$, Sahat Siagian ${ }^{2}$, Harun Sitompul $^{3}$ \\ ${ }^{1}$ Program Studi Pendidikan Seni Musik, FBS Universitas Negeri Medan, Sumatera Utara \\ ${ }^{2,3}$ FT Universitas Negeri Medan, Sumatera Utara \\ deslinasimamora@yahoo.com
}

\begin{abstract}
Abstrak:Penelitian ini bertujuan untuk mengetahui: hasil belajar piano mahasiswa yang diajar dengan multimedia $C D$ Interaktif dibandingkan dengan mahasiswa yang diajar dengan multimedia pembelajaran CD Program; hasil belajar piano mahasiswa yang memiliki kecerdasan musikal tinggi dengan hasil belajar mahasiswa yang memiliki kecerdasan musikal rendah; mengetahui interaksi antara pembelajaran multimedia dan kecerdasan musikal mahasiswa terhadap hasil belajar Piano. Metode penelitian adalah metode kuasi eksperimen dengan sampel penelitian sebanyak 2 kelas yang ditentukan secara cluster random sampling terdiri dari kelas ekperimerimen yang diajarkan dengan multimedia CD interaktif dan multimedia CD Program. Hasil penelitian menunjukkan: (1) hasil belajar piano mahasiswa yang diajarkan dengan multimedia CD Interaktif lebih baik dari pada hasil belajar piano mahasiswa yang diajarkan dengan multimedia pembelajaran CD Program, hasil belajar Piano mahasiswa yang memiliki kecerdasan musikal lebih baik dari pada hasil belajar Piano mahasiswa yang memiliki kecerdasan musikal rendah, terdapat interaksi antara pembelajaran multimedia dengan kecerdasan musikal dalam mempengaruhi hasil belajar mahasiswa.
\end{abstract}

Kata kunci : Multimedia pembelajaran interaktif, kecerdasan musikal, dan hasil belajar piano.

\begin{abstract}
This research aimed to determine: learning outcomes piano students taught with interactive CD Instruction multimedia than students who are taught with Instruction multimedia CD program, learning outcomes piano students with high musical intelligence than the students whose low musical intelligence, determine the interaction between multimedia learning and musical intelligence of students towards learning outcomes of piano. Method is a mettod of quasiexperimental studi with a sampel of 2-class research determined clucter random sampling exsperiment consists of classes taught interactive $C D$ and interactive program $C D$.The results showed: learning outcomes piano students those taught with interactive CD learning was better than learning outcomes piano of the student those taught by CD program, learning outcomes piano of the students who se high musical intelligence was better than learning outcomes piano of the students whose low musical intelligence, there are interaction between multimedia learning and musical intelligence in affecting student learning outcomes.
\end{abstract}

Keywords: Interactive multimedia learning, musical intelligence and student learning outcomes of piano.

PENDAHULUAN

jasmani maupun rohani sesuai dengan nilai- nilai

Pendidikan adalah aspek universal yang yang ada di dalam masyarakat dan kebudayaan. selalu dan harus ada dalam kehidupan manusia Perguruan Tinggi sebagai institusi (Indriana, 2011:5). Tanpa pendidikan, manusia pendidikan formal berupaya merealisasikan tidak akan pernah berkembang dantujuan pendidikan melalui penyelenggaraan berkebudayaan. Dalam pengertian yang sederhana proses belajar mengajar dalam rangka dan umum makna pendidikan sebagai usahameningkatkan kualitas lulusan mahasiswa manusia untuk menumbuhkan dan sehingga memiliki kompetensi yang berguna mengembangkan potensi- potensi pembawaan baikdalam kehidupan pribadi, kehidupan 
bermasyarakat, dan kehidupan bernegara. Keberhasilan peningkatan kompetensi lulusan haruslah didukung dengan banyak faktor, salah satu yang terpenting adalah peran seorang pengajar yang dapat menentukan keberhasilan pembelajaran, karena fungsi utama pengajar ialah merancang, mengelola, dan mengevaluasi pembelajaran.

Program pendidikan seni musik merupakan salah satu jurusan di perguruan tinggi di Universitas Negeri Medan. Proses pembelajaran di jurusan Pendidikan seni musik dilaksanakan dengan cara mentransfer sejumlah pengetahuan tentang seni musik di samping muatan efektif dalam pendidikan. Pendidikan di Universitas Negeri Medan khususnya program studi pendidikan seni musik sangat diharapkan untuk mencetak mahasiswa yang benar-benar siap mempraktikkan keahliannya sebagai salah satu bekal ketrampilan untuk hidup di masyarakat setelah lulus nanti. Selain itu jurusan program studi pendidikan seni musik memang diharapkan dapat mencetak generasi penerus di bidang musik dan menciptakan pengajar seni musik yang berkualitas dan berbakat dalam bidang seni musik.

Semua mahasiswa di jurusan program studi pendidikan seni musik Fakultas Bahasa dan Seni Universitas Negeri Medan dituntut mempunyai keterampilan bermusik yang memadai dan mempunyai intelektual yang tinggi, karena itu salah satu faktor terpenting sebagai salah satu syarat menjadi pemusik dan pengajar seni musik. Selain itu diharapkan agar mahasiswa mempunyai mutu yang berkualitas, mutu pendidikan di lingkungan sekolah atau sebuah lembaga kependidikan, dapat dikatakan berkualitas apabila pendidikan yang dilaksanakan dapat memberikan lulusannya kemampuan, pengetahuan, dan ketrampilan yang berguna untuk melanjutkan ke tingkat pendidikan yang lebih tinggi maupun untuk memasuki dunia kerja. Pendidikan seni musik memiliki fungsi yang besar dalam kehidupan, karena seni musik melatih keseimbangan otak kanan dan otak kiri, hal ini tidak terdapat pada mata pelajaran umum yang lainnya. Pembaharuan dan pengembangan dibidang pendidikan sangat diperlukan untuk menciptakan pendidikan berkualitas yang sesuai dengan kebutuhan masyarakat yang selalu maju dan berkembang. Hal ini akan tercapai apabila proses belajar mengajar dilaksanakan secara efektif sehingga hasil pendidikan yang akan dicapai dapat optimal..
Hasil temu wicara dalam perkuliahan dengan mahasiswa Program Studi Seni Musik Fakultas Bahasa dan seni UNIMED Tahun ajaran 2014 menemukan bahwa kebanyakan dari mereka banyak mendapat nilai yang rendah dan tidak berani menjadi pengajar les piano disebabkan kekurang mampuannya bermain piano. Berikut ini pada Tabel 1, hasil belajar piano mahasiswa jurusan pendidikan seni musik.

Dalam rangka peningkatan mutu pembelajaran Piano di program studi pendidikan seni musik FBS UNIMED, banyak faktor yang perlu diteliti terutama yang berhubungan dengan pembelajaran piano. Kondisi yang dapat diamati dan dijumpai banyak mahasiswa mengalami kesulitan dalam mempelajari konsep-konsep mata kuliah piano, tidak familiarnya dengan istilah teknologi sehingga mengalami kesulitan dalam menggunakan teknologi. Keterbatasan pengajar dalam mendesain dan mengelola media pembelajaran sehingga membuat mahasiswa kurang tertarik dan kurang termotivasi dalam belajar. Ketepatan penggunaan media pembelajaran akan memberikankontribusi terhadap pencapaian tujuan pembelajaran.

Untuk dapat mengoptimalkan pelajaran mata kuliah piano, salah satu cara untuk memperbaiki pembelajaran adalah dengan menggunakan multimedia. Kehadiran multimedia pembelajaran sebagai media antara pengajar sebagai pengirim informasi dan penerima informasi harus komunikatif, masingmasing media mempunyai keistimewaan menurut karakteristik mahasiswa. Pemilihan media yang sesuai dengan karakteristik siswa akan lebih membantu keberhasilan pengajar dalam pembelajaran. Secara rinci fungsi media memungkinkan mahasiswa menyaksikan obyek yang ada tetapi sulit untuk dilihat dengan kasat mata melalui perantaraan gambar, potret, slide, dan sejenisnya mengakibatkan mahasiswa memperoleh gambaran yang nyata (Degeng,1999:19).

Selain penggunaan multimedia pembelajaran, kemampuan dalam memainkan alat musik sangat dipengaruhi oleh kecerdasan musikal, Kecerdasan memegang peranan penting dalam menentukan berhasil tidaknya seserorang. Orang cerdas pada umumnya lebih mampu belajar daripada orang yang kurang cerdas. Berbagai penelitian menunjukkan hubungan yang erat antara tingkat kecerdasan dan hasil belajar di sekolah (Sumadi, 1989: 11). 
Individu yang memiliki kecerdasan musikal yang tinggi akan berperan untuk menyerap pembelajaran dengan baik.

Kecerdasan musik merupakan bagian dari kecerdasan jamak yang berkaitan dengan kepekaan mendengarkan suara musik dan suara lainnya. Kemunculan kecerdasan ini dilihat dari kemampuan menghasilkan dan mengapresiasi ritme dan musik yang dapat diwujudkan dalam kemampuan mempersepsikan. Kecerdasan ini merupakan salah satu kecerdasan teori multiple intelegensi yang dikembangkan oleh

Howard Gardner, pengajar besar dari Havarrd University, AS. Menurutnya, kecerdasan bermusik mencakup kepekaan dan penguasaan nada, irama, pola-pola ritme, tempo, instrument, dan ekspresi musik, hingga seseorang dapat menyanyikan lagu, bermain musik dan menikmati musik. Berdasarkan uraian di atas sangat menarikmengetahui pengaruh multimedia pembelajaran dan kecerdasan musik terhadap hasil belajar piano.

\section{METODE}

Populasi penelitian ini adalah seluruh mahasisiwa piano angkatan 2014 Semester ganjil yaitu pada semester 3 (tiga) program studi pendidikan seni musik Fakultas Bahasa dan Seni Universitas Negeri Medan, yang berjumlah 115 orang. Sesuai dengan jadwal perkuliahan piano yang ditetapkan oleh jurusan dijadikan menjadi dua kelas. Mahasiswa Program Studi Seni Musik Semester 2 (dua) Tahun Akademik 2014/ 2015 yang berjumlah 36 orang kelas Piano 1 (satu) dan 34 orang kelas Piano 2 (dua). Mahasiswa diambil secara cluster random dengan penggunaan multimedia CD Interaktif dan kelas eksperimen yang lain dibelajarkan dengan penggunaan multimedia CD Program.

Teknik penentuan sampel digunakan cluster random sampling berdasarkan dimensi kecerdasan yang dimiliki, seluruh mahasiswa dikelompokkan menjadi dua kelompok sehingga setiap kelompok atau kelas terdiri dari kelompok I (orang yang memiliki kecerdasan musik tinggi) dan kelompok II (orang yang memiliki kecerdasan musik rendah). Desain penelitian menggunakan faktorial 2 x 2 . Rancangan penelitian ini akan membandingkan media CD Interaktif dan CD Program diperlakukan kepada kelompok mahasiswa yang mempunyai kecerdasan musikal yang berbeda. Multimedia pembelajaran sebagai variabel bebas, perbedaan kecerdasan musik sebagai variabel moderator dan perolehan hasil belajar
Hasil penelitian (Susiana, 2013) menemukan bahwa terdapat perbedaan hasil belajar kelas eksperimen dan kelas kontrol pada ranah kognitif. Perbedaan ini diyakini disebabkan oleh pengaruh penggunaan multimedia. Dengan demikian, dapat disimpulkan bahwa penggunaan multimedia dapat meningkatkan hasil belajar, juga menemukan bahwa penggunaan multimedia berpengaruh positif terhadap peningkatan hasil belajar mahasiswa pada mata piano. Hasil penelitian sebelumnya yang menemukan adanya pengaruh penggunaan multimedia terhadap hasil belajar siswa maka peneliti tertarik untuk melakukan penelitian percobaan pada mata kuliah piano di jurusan seni musik. Maka judul penelitian ini adalah " Pengaruh Multimedia Pembelajaran Dan Kecerdasan Musikal Terhadap Hasil Belajar Piano Mahasiswa Jurusan Pendidikan Seni Musik Universitas Negeri Medan"

piano sebagai variabel terikat. Teknik analisis data yang digunakan adalah teknik statistika Deskriptif dan Inferensial. Teknik statistik deskriptif digunakan untuk mendeskripsikan data, sedangkan teknik statistik Inferensial digunakan untuk menguji hipotesis penelitian. Hipotesis penelitian diuji dengan teknik analisis varians dua jalur (desain faktorial $2 \times 2$ ) dengan tarif signifikan $5 \%$. Syarat untuk menggunakan ANAVA dua jalur adalah : (1) diambil secara acak, (2) harus berdistribusi normal, (3) harus memiliki varians populasi yang homogen. Sebelum ANAVA dua jalur dilakukan, terlebih dahulu dilakukan uji persyaratan normalitas data dengan menggunakan uji Liliefors, sedangkan untuk melihat homogenitas varians digunakan uji Fisher dan uji Barlet. Jika dalam pengujian ANAVA ternyata terdapat interaksi multimedia pembelajaran interaktif dan kecerdasan musical terhadap hasil belajar piano yang signifikan, maka dilakukan uji lanjut. Dalam penelitian karena sampel tiap sel berbeda (n berbeda) maka uji lanjut dilakukan dengan uji Scheffe.

\section{HASIL DAN PEMBAHASAN Deskripsi Data Hasil Penemuan}

Data hasil penelitian dikelompokkan berdasarkan interaksi multimedia pembelajaran interaktif dengan kecerdasan musical mahasiswa. Perbandingan kelompok data-data hasil belajar piano terangkum dalam tabel 1 . 
JURNAL TEKNOLOGI INFORMASI \& KOMUNIKASI dalam PENDIDIKAN, Vol. 5 No. 1 Juni 2018,

p-ISSN; 2355-4983, e-ISSN: 2407-7488

Tabel 1 Rangkuman Hasil Analisi Statistik Deskriptif

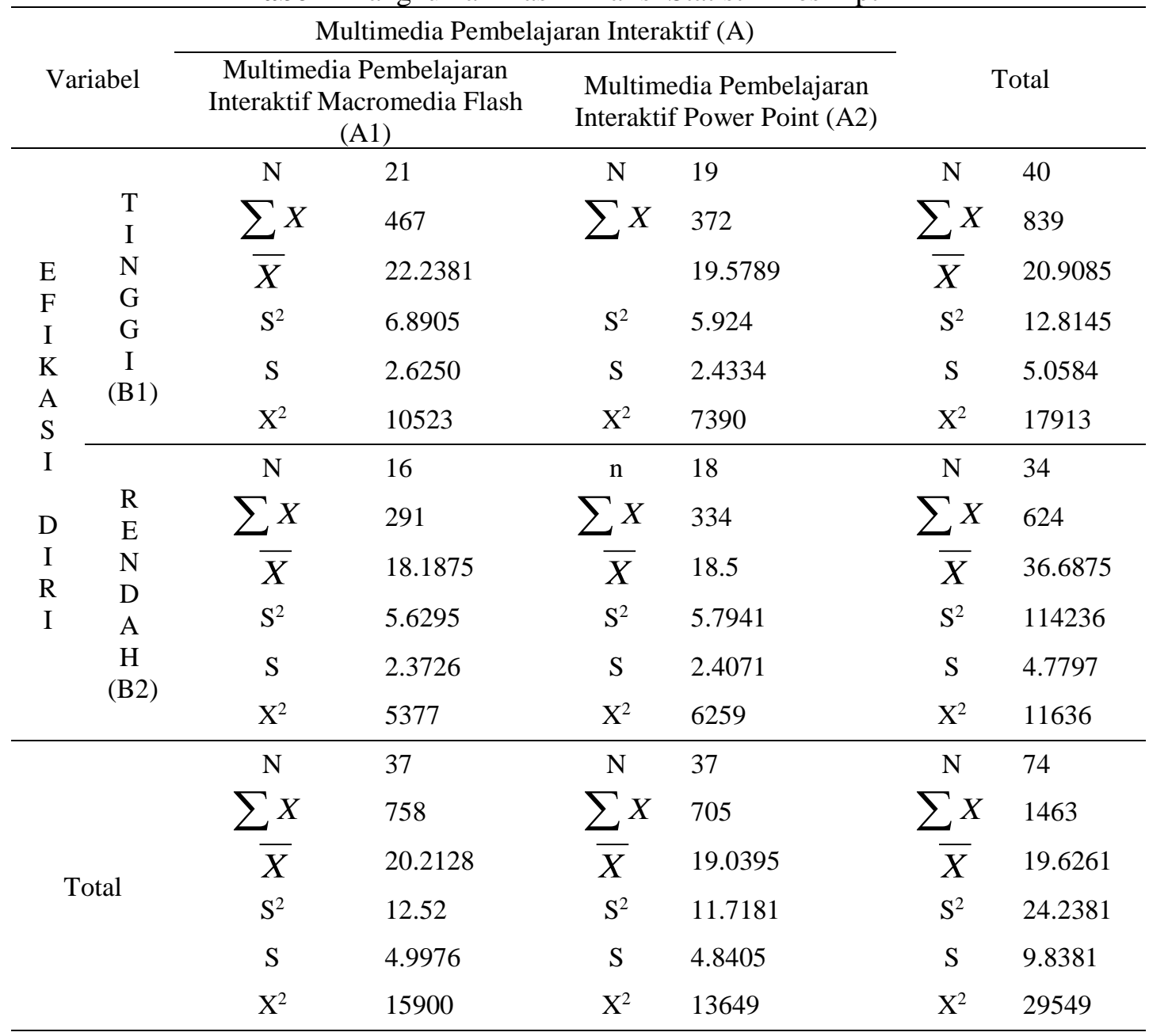

\section{Uji Normalitas Data}

Uji normalitas dilakukan dengan uji Liliefors.

Perhitungan selengkapnya dapat dilihat pada
Lampiran • Rangkuman perhitungan dengan formula Liliefors pada dilihat pada Tabel 2 dan berikut.

Tabel 2 Hasil Analisis Uji Normalitas Hasil Belajar Piano Mahasiswa yang Menggunakan Multimedia.

\begin{tabular}{clccc}
\hline NO & \multicolumn{1}{c}{ Kelompok } & Lo & Lt & Ket \\
\hline 1 & $\begin{array}{l}\text { Hasil belajar piano mahasiswa yang dibelajarkan dengan } \\
\text { menggunakan multimedia CD interktif }\end{array}$ & 0,109 & 0.147 & Normal \\
\hline 2 & $\begin{array}{l}\text { Hasil belajar piano mahasiswayang dibelajarkan dengan } \\
\text { menggunakan multimedia CD Program }\end{array}$ & 0,074 & 0,151 & Normal \\
\hline
\end{tabular}

Uji kenormalan data hasil belajar piano mahasiswa yang dibelajarkan dengan menggunakan Multimedia CD Interaktif diperoleh Liliefors hitung sebesar 0,109 sedangkan nilai Liliefors hitung dari tabel sebesar 0,147 pada $\alpha=0.05$ dan $\mathrm{N}=36$. Dengan demikian maka diketahui bahwa nilai Liliefors hitung lebih kecil dari nilai Liliefors tabel yaitu $0,109<0,147$ maka disimpulkan bahwa data hasil belajar piano dengan menggunakan Multimedia CD Interaktif berasal dari populasi berdistribusi normal.

Uji kenormalan data hasil belajar piano mahasiswa yang dibelajarkan dengan menggunakan multimedia CD Program diperoleh Liliefors hitung sebesar 0,074 sedangkan nilai Liliefors hitung dari tabel sebesar 0,151 pada $\alpha=0.05$ dan $\mathrm{N}=34$. 
Dengan demikian maka diketahui bahwa nilai Liliefors hitung lebih kecil dari nilai Liliefors tabel yaitu $0,109<0,152$ maka disimpulkan bahwa data hasil belajar piano dengan menggunakan Multimedia CD Program berasal dari populasi berdistribusi normal. hasil analisis uji normalitas hasil belajar piano mahasiswa yang memiliki kecerdasan musikal dapat dilihat pada tabel 3 berikut.

Tabel 3. Hasil Analisis Uji Normalitas Hasil Belajar Piano Mahasiswa yang Memiliki Kecerdasan musikal

\begin{tabular}{clccc}
\hline NO & \multicolumn{1}{c}{ Kelompok } & Lo & Lt & Ket \\
\hline 1 & $\begin{array}{l}\text { Hasil belajar piano mahasiswayang memiliki } \\
\text { memiliki kecerdasan musikal tinggi. }\end{array}$ & 0,72 & 0.147 & Normal \\
\hline 2 & $\begin{array}{l}\text { Hasil belajar piano mahasiswayang memiliki } \\
\text { kecerdasan musikal rendah. }\end{array}$ & 0,078 & 0,151 & Normal \\
\hline
\end{tabular}

Uji kenormalan data hasil belajar piano mahasiswa yang memiliki memiliki kecerdasan musikal tinggi diperoleh Liliefors hitung sebesar 0,072 sedangkan nilai Liliefors hitung dari tabel sebesar 0.147 pada $\alpha=0.05$ dan $\mathrm{N}=36$. Dengan demikian maka diketahui bahwa nilai Liliefors hitung lebih kecil dari nilai Liliefors tabel yaitu $0,72<0,147$ maka disimpulkan bahwa data hasil belajar piano mahasiswa yang memiliki memiliki kecerdasan musikal tinggi berasal dari populasi berdistribusi normal. Uji kenormalan data hasil belajar piano mahasiswa yang memiliki memiliki kecerdasan musikal rendah diperoleh Liliefors hitung sebesar 0,078 sedangkan nilai Liliefors hitung dari tabel sebesar 0,151 pada $\alpha=0.05$ dan $\mathrm{N}=34$. Dengan demikian maka diketahui bahwa nilai Liliefors hitung lebih kecil dari nilai Liliefors tabel yaitu $0,078<$ 0,151 maka disimpulkan bahwa data hasil belajar piano mahasiswa yang memiliki memiliki kecerdasan musikal berasal dari populasi berdistribusi normal. Hasil analisis uji normalitas hasil belajar piano mahaiswa yang menggunakan multimedia dapat dilihat pada Tabel 4. berikut.

Tabel 4. Hasil Analisis Uji Normalitas Hasil Belajar Piano Mahaiswa yang Menggunakan Multimedia.

\begin{tabular}{clccc}
\hline No & \multicolumn{1}{c}{ Kelompok } & Lo & Lt & Ket \\
\hline 1 & $\begin{array}{l}\text { Uji normalitas data hasil belajar piano mahasiswa yang } \\
\text { memiliki kecerdasan musikal tinggi yang dibelajarkan } \\
\text { dengan menggunakan Multimedia CD Interaktif. }\end{array}$ & 0,091 & 0,208 & Normal \\
\hline 2 & $\begin{array}{l}\text { Uji normalitas data hasil belajar piano mahasiswa yang } \\
\text { memiliki kecerdasan musikal tinggi yang dibelajarkan } \\
\text { dengan menggunakan Multimedia CD Program. }\end{array}$ & 0,136 & 0,208 & Normal \\
\hline 3 & $\begin{array}{l}\text { Uji normalitas data hasil belajar piano mahasiswa yang } \\
\text { memiliki kecerdasan musikal rendah yang dibelajarkan } \\
\text { dengan menggunakan Multimedia CD Interaktif. }\end{array}$ & 0,153 & 0,208 & Normal \\
\hline 4 & $\begin{array}{l}\text { Uji normalitas data hasil belajar piano mahasiswa yang } \\
\text { memiliki kecerdasan musikal rendah yang dibelajarkan } \\
\text { dengan menggunakan Multimedia CD Program. }\end{array}$ & 0.101 & 0,221 & Normal \\
\hline
\end{tabular}

Uji kenormalan data hasil belajar piano mahasiswa yang memiliki memiliki kecerdasan musikal tinggi dengan menggunakan Multimedia CD Interaktif diperoleh Liliefors hitung sebesar 0,091 sedangkan nilai Liliefors hitung dari tabel sebesar 0,208 pada $\alpha=0.05$ dan $\mathrm{N}=18$. Dengan demikian maka diketahui bahwa nilai Liliefors hitung lebih kecil dari nilai Liliefors tabel yaitu $0,091<0,208$ maka disimpulkan bahwa data hasil belajar piano mahasiswa yang memiliki memiliki kecerdasan musikal tinggi dengan menggunakan Multimedia CD Interaktif berasal dari populasi berdistribusi normal.

Uji kenormalan data hasil belajar piano mahasiswa yang memiliki memiliki kecerdasan musikal tinggi dengan menggunakan Multimedia CD Program diperoleh Liliefors 
hitung sebesar 0,136 sedangkan nilai Liliefors hitung dari tabel sebesar 0,208 pada $\alpha=0.05$ dan $\mathrm{N}=18$. Dengan demikian maka diketahui bahwa nilai Liliefors hitung lebih kecil dari nilai Liliefors tabel yaitu $0,136<0,208$ maka disimpulkan bahwa data hasil belajar piano mahasiswa yang memiliki memiliki kecerdasan musikal dengan menggunakanMultimedia CD Program berasal dari populasi berdistribusi normal.

Uji kenormalan data hasil belajar piano mahasiswa yang memiliki memiliki kecerdasan musikal rendah dengan menggunakan multimedia CD interaktif diperoleh Liliefors hitung sebesar 0,153 sedangkan nilai Liliefors hitung dari tabel sebesar 0,208 pada $\alpha=0.05$ dan $\mathrm{N}=18$. Dengan demikian maka diketahui bahwa nilai Liliefors hitung lebih kecil dari nilai Liliefors tabel yaitu $0,153<0,208$ maka disimpulkan bahwa data hasil belajar piano mahasiswayang memiliki memiliki kecerdasan musikal trendah dengan menggunakan Multimedia CD Interaktif berasal dari populasi berdistribusi normal.

Uji kenormalan data hasil belajar piano mahasiswayang memiliki memiliki kecerdasan musikal rendah dengan menggunakan
Multimedia CD Program diperoleh Liliefors hitung sebesar 0,101 sedangkan nilai Liliefors hitung dari tabel sebesar 0,221 pada $\alpha=0.05$ dan $\mathrm{N}=16$. Dengan demikian maka diketahui bahwa nilai Liliefors hitung lebih kecil dari nilai Liliefors tabel yaitu $0,101<0,222$ maka disimpulkan bahwa data hasil belajar piano mahasiswayang memiliki memiliki kecerdasan musikal rendah dengan menggunakan Multimedia CD Program berasal dari populasi berdistribusi normal.

\section{Uji Homgenitas Varians Data}

Uji Homogenitas Data Hasil Belajar Piano mahasiswa yang Dibelajarkan dengan Menggunakan Multimedia CD Interaktif dengan Multimedia CD Program serta Kecerdasan musikal Tinggi dan Kecerdasan musikal Rendah

Untuk menentukan homogenitas data hasil belajar piano yang dibelajarkan dengan Multimedia CD Interaktif dan Multimedia CD Program serta kecerdasan musikal tinggi dan kecerdasan musikal rendah dilakukan dengan menggunakan uji varians terbesar dibandingkan dengan varians terkecil.

Tabel 5. Pengujian Homogenitas Kelompok Sampel Hasil Belajar Piano mahasiswayang Dibelajarkan Menggunakan Multimedia CD Interaktif denganMultimedia CD Program

\begin{tabular}{|c|c|c|c|c|c|c|}
\hline Sampel & $\mathrm{N}$ & $\mathrm{dk}$ & Varians & $F_{\text {hitung }}$ & $\mathrm{F}_{\text {tabel }}$ & Keterangan \\
\hline Multimedia CD Interaktif & 36 & & 50.828 & \multirow{2}{*}{1.690} & \multirow{2}{*}{1.756} & \multirow{2}{*}{ Homogen } \\
\hline Multimedia CD Program & 34 & & 30.068 & & & \\
\hline
\end{tabular}

Uji homogenitas data hasil belajar kelompok sampel yang dibelajarkan dengan multimedia CD interaktif dan Multimedia CD Program diperoleh nilai $F_{\text {hitung }}$ lebih kecil dari $\mathrm{F}_{\text {tabel }}$, yaitu $(1.690)<(1,756)$, sehingga dapat disimpulkan bahwa data hasil belajar piano mahasiswa untuk kelompok yang diajar multimedia CD interaktif dan Multimedia CD Program memiliki varians homogen.

Tabel 6 Rangkuman Hasil Pengujian Homogenitas Kelompok Sampel Hasil Belajar Piano mahasiswadengan Kecerdasan musikal Tinggi dan Kecerdasan musikal Rendah

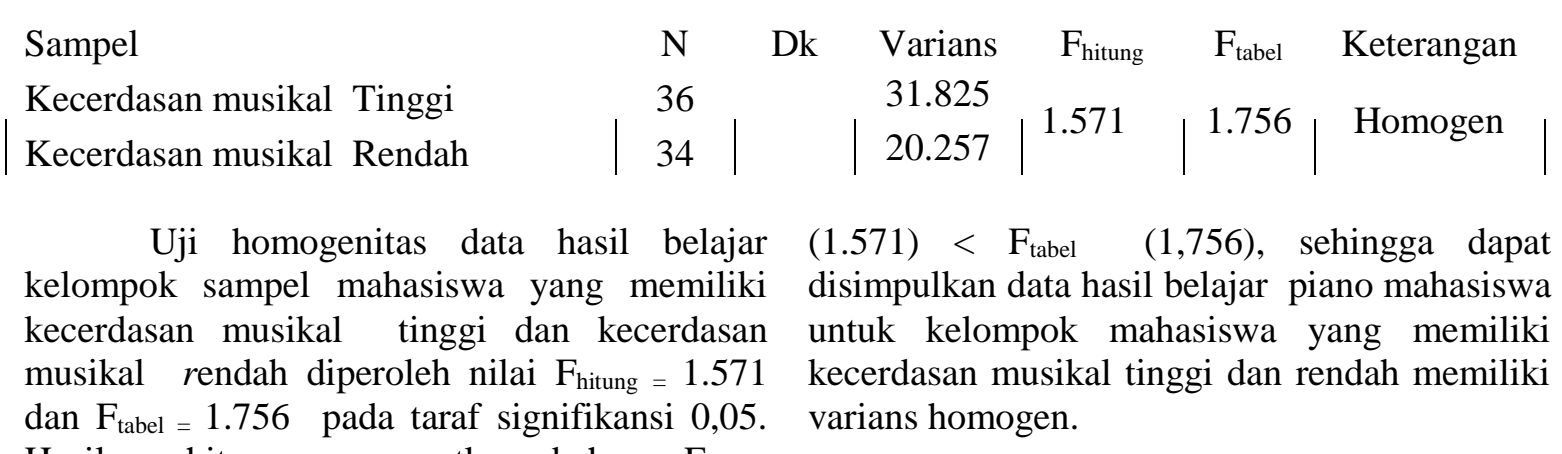


Pengujian Homogenitas Interaksi Kelompok Sampel Multimedia CD Interaktifdengan Kelompok Sampel Kecerdasan musikal

Pengujian homogenitas varians sampel dilakukan dengan uji Barlett. Rangkuman perhitungan interaksi multimedia CD interaktif dan kecerdasan musikal dapat dilihat pada Tabel 7 di bawah ini.

Tabel 7. Rangkuman Hasil Pengujian Homogenitas dengan Uji Bartlet

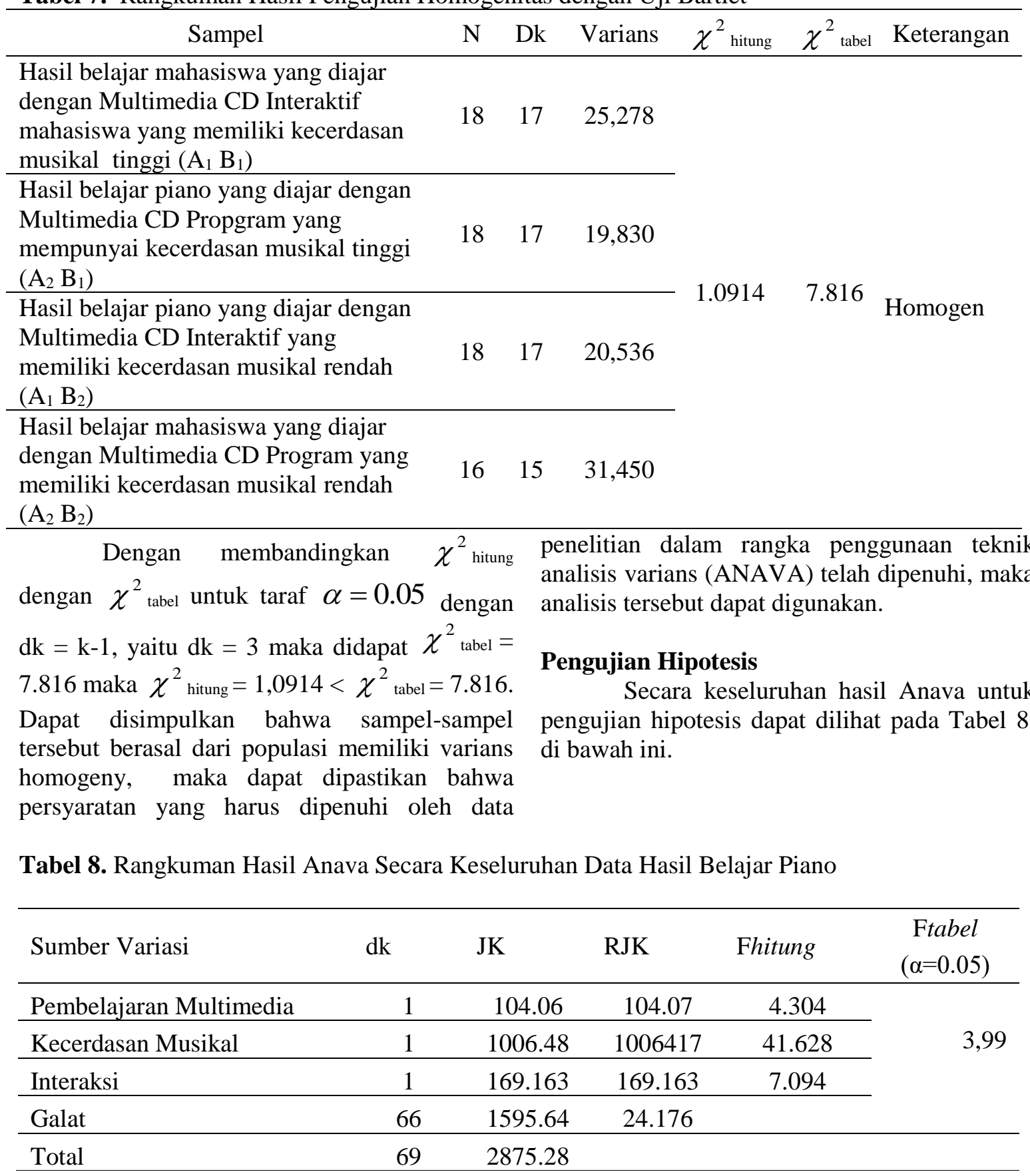


Berdasarkan rangkuman di atas maka akan dirinci pengujian hipotesis sebagai berikut:

Perbedaan Hasil Belajar Piano Antara Mahasiswa yang Memperoleh Multimedia CD Interaktif Dan CD Program adalah:

Adapun hipotesis statistik yang diuji

$$
\begin{aligned}
& \text { Ho : } \mu A_{1} \leq \mu A_{2} \\
& \text { Ha : } \mu A_{1}>\mu A_{2}
\end{aligned}
$$

Pernyataan hipotesis tersebut adalah :

Berdasarkan hasil pengujian hipotesis pada Tabel 4.16 di atas, maka diperoleh hasil perhitungan data multimedia, dimana $\mathrm{F}_{\text {hitung }}=$ 4,304 sementara nilai kritik $\mathrm{F}_{\text {tabel }}$ dengan $\mathrm{dk}=$ $(1,66) \operatorname{dan} \alpha=0,05$ adalah sebesar 3,98. Hasil ini menunjukkan bahwa $\mathrm{F}_{\text {hitung }}=4,304>\mathrm{F}_{0,05}$ $(1,66)=3,99$ sehingga hipotesis $\mathrm{Nol}(\mathrm{Ho})$ ditolak dan menerima Ha. Dengan demikian dapat ditarik kesimpulan, bahwa hasil belajar piano mahasiswa yang dibelajarkan dengan multimedia CD interaktif lebih tinggi dari hasil belajar piano mahasiswa yang diajar
denganMultimedia CD Program teruji kebenarannya secara empirik.

Perbedaan Hasil Belajar Piano Antara Siswa yang Memiliki Kecerdasan Musikal Tinggi Dan Rendah

$$
\text { Adapun hipotesis statistik yang diuji }
$$
adalah:

$$
\begin{aligned}
& \text { Ho : } \mu B_{1} \leq \mu B_{2} \\
& \text { Ha : } \mu B_{1}>\mu B_{2}
\end{aligned}
$$

Berdasarkan hasil pengujian hipotesis pada Tabel 4.16 di atas, maka diperoleh hasil perhitungan data kecerdasan musikal , dimana $\mathrm{F}_{\text {hitung }}=41,628$ sementara nilai kritik $\mathrm{F}_{\text {tabel }}$ dengan $\mathrm{dk}=(1,66) \quad$ dan $\alpha=0,05$ adalah sebesar 3,98. Hasil ini menunjukkan bahwa Fhitung $=41,628>F_{\text {tabel }} 3,98$ sehingga hipotesis Nol (Ho) ditolak. Dengan demikian dapat ditarik kesimpulan, bahwa hipotesis penelitian yang menyatakan hasil belajar piano mahasiswa mempunyai kecerdasan musikal tinggi lebih tinggi dari hasil belajar piano yang mempunyai kecerdasan musikal rendah dapat teruji kebenarannya secara empirik.

Tabel 9. Ringkasan Hasil Uji Scheffe

\begin{tabular}{cccccl}
\hline No & \multicolumn{2}{c}{ Interaksi } & $\mathrm{F}_{\text {Hitung }}$ & $\mathrm{F}_{\text {Tabel }} \alpha=0.05$ & Keterangan \\
\hline $\mathbf{1}$ & $\mu \mathrm{A}_{1} \mathrm{~B}_{1}$ & $\mu \mathrm{A}_{2} \mathrm{~B}_{1}$ & 3.577 & 2.73 & Signifikan \\
$\mathbf{2}$ & $\mu \mathrm{A}_{1} \mathrm{~B}_{1}$ & $\mu \mathrm{A}_{2} \mathrm{~B}_{2}$ & 6.011 & 2.73 & Signifikan \\
$\mathbf{3}$ & $\mu \mathrm{A}_{1} \mathrm{~B}_{1}$ & $\mu \mathrm{A}_{1} \mathrm{~B}_{2}$ & 6.410 & 2.73 & Signifikan \\
$\mathbf{4}$ & $\mu \mathrm{A}_{2} \mathrm{~B}_{1}$ & $\mu \mathrm{A}_{2} \mathrm{~B}_{2}$ & 3,052 & 2.73 & Signifikan \\
$\mathbf{5}$ & $\mu \mathrm{A}_{2} \mathrm{~B}_{2}$ & $\mu \mathrm{A}_{2} \mathrm{~B}_{1}$ & 2,925 & 2.73 & Signifikan \\
$\mathbf{6}$ & $\mu \mathrm{A}_{2} \mathrm{~B}_{2}$ & $\mu \mathrm{A}_{1} \mathrm{~B}_{2}$ & 0,196 & 2.73 & Tidak Signifikan \\
\hline
\end{tabular}

a. Dari hasil perhitungam dengan uji Scheffe pada Tabel $4.17 \mathrm{di}$ atas, diperoleh hasil perhitungan data dimana $F_{\text {hitung }}=3,577$ sementara nilai kritik $F_{\text {tabel }}$ sebesar 2,73 Sehingga Hipotesis Nol (Ho) ditolak. Dengan demikian, hipotesis penelitian yang menyatakan bahwa terdapat interaksi multimedia kecerdasan musikal dalam memberikan pengaruh terhadap hasil belajar piano mahasiswa teruji kebenarannya.

b. Dari hasil perhitungam dengan uji Scheffe pada Tabel 4.17 di atas, diperoleh hasil perhitungan data dimana $F_{\text {hitung }}=6,410>$ $\mathrm{F}_{\text {tabel }} 2,73$, sehingga Hipotesis Nol (Ho) ditolak. Dengan demikian, hipotesis penelitian yang menyatakan bahwa hasil belajar piano mahasiswa yang memiliki kecerdasan musikal tinggi dan diajar dengan menggunakan multimedia $\mathrm{CD}$ interaktif lebih tinggi dibandingkan dengan siswa yang memiliki kecerdasan musikal rendah dan diajarMultimedia CD Program teruji kebenarannya.

c. Dari hasil perhitungam dengan uji Scheffe pada Tabel 4.17 di atas, diperoleh hasil perhitungan data dimana $F_{\text {hitung }}=3,052>F_{\text {tabel }}$ $=2,73$, sehingga Hipotesis Nol (Ho) ditolak. Dengan demikian, hipotesis penelitian yang menyatakan bahwa hasil belajar piano mahasiswa yang memiliki kecerdasan musikal tinggi dan diajar dengan menggunakan multimedia $\mathrm{CD}$ interaktif 
lebih tinggi dibandingkan dengan siswa yang memiliki kecerdasan musikal rendah dan diajar Multimedia CD Program teruji kebenaran.

d. Dari hasil perhitungam dengan uji Scheffe pada Tabel 4.17 di atas, diperoleh hasil perhitungan data dimana $F_{\text {hitung }}=0.196>F_{\text {tabel }}$ $=2,73$, sehingga memberikan keputusan menerima Ho. Dengan demikian, hipotesis penelitian yang menyatakan bahwa hasil belajar piano mahasiswa yang memiliki kecerdasan musikal rendah dan diajar dengan menggunakanMultimedia CD Program lebih tinggi dibandingkan dengan mahasiswa yang memiliki kecerdasan musikal tinggi dan diajar Multimedia CD Program tidak teruji kebenarannya.

e. Dari hasil perhitungam dengan uji Scheffe pada Tabel 4.17 di atas, diperoleh hasil perhitungan data dimana $F_{\text {hitung }}=2,952<\mathrm{F}_{\text {tabel }}$ $=2,73$, sehingga memberikan keputusan menerima Ho. Dengan demikian, hipotesis penelitian yang menyatakan bahwa hasil belajar piano mahasiswa yang memiliki kecerdasan musikal tinggi dan diajar dengan menggunakan Multimedia CD Program lebih tinggi dibandingkan dengan siswa yang memiliki kecerdasan musikal rendah dan diajar Multimedia CD Interaktif tidak teruji kebenarannya.

f. Dari hasil perhitungam dengan uji Scheffe pada Tabel 4.17 di atas, diperoleh hasil perhitungan data dimana $F_{\text {hitung }}=0.196<$ $\mathrm{F}_{\text {tabel }}=2,73$, sehingga menerima Ho. Dengan demikian, hipotesis penelitian yang menyatakan bahwa hasil belajar piano mahasiswa yang memiliki kecerdasan musikal rendah dan diajar dengan menggunakan Multimedia CD Program lebih tinggi dibandingkan dengan siswa yang memiliki kecerdasan musikal rendah dan diajar Multimedia CD Interaktif tidak teruji kebenarannya.

Hasil pengujian lanjut di atas, menunjukkan adanya interaksi antara multimedia dan kecerdasan musikal terhadap hasil belajar piano mahasiswa dapat ditunjukkan seperti pada Gambar 1 berikut.

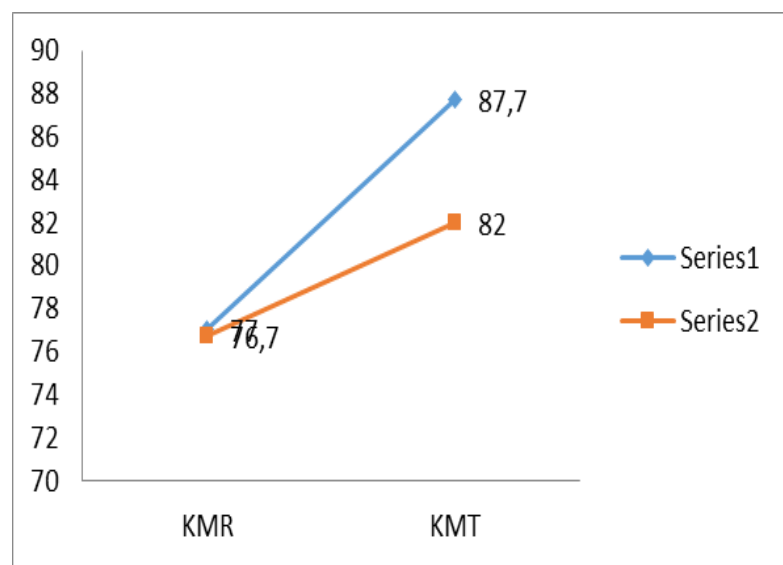

Gambar 1 Interaksi antara multimedia dan kecerdasan musikal

KMR :Kecerdasan Musikal rendah

KMT : Kecerdasan Musikal Tinggi

\section{PEMBAHASAN}

Perbedaan Hasil Belajar Piano Mahasiswa yang Diajarkan dengan Menggunakan Multimedia CD Interaktif dengan Multimedia CD Program

Dari hasil pengolahan data yang dilakukan terdapat perbedaan hasil belajar piano antara mahasiswa yang dibelajarkan dengan Multimedia CD Interaktif dan Multimedia CD Program yaitu rata-rata hasil belajar piano yang dibelajarkan dengan menggunakan Multimedia CD Interaktif lebih tinggi dibandingkan dengan mahasiswa yang diajarkan dengan mahasiswa yang dibelajarkan dengan menggunakan Multimedia CD Program.

Penggunaan Multimedia CD Interaktif dalam pembelajaran piano memungkinkan mahasiswa untuk berinteraksi langsung dan melakukan kontrol langsung pada sumber informasi sehingga memungkinkan mahasiswa untuk menemukan informasi yang sedang dipelajari. Pembelaran dengan Multimedia CD Interaktif memungkinkan guru bebas melakukan interaksi dengan mahasiswa sehingga bersifat interaktif yang membuat pembelajaran terfokus pada informasi yang dipelajari. Pada pembelajaran ini guru mengacu pada penyajian informasi akademik yang baru yang penyampainnya dapat dihentikan pada setiap urutan-urutan yang dikehendaki sehingga siswa tidak mengalami banyak kesulitan untuk mengikuti proses dan mahasiswa dapat mengulang sejenak suatu informasi yang kurang dipahami. Dengan menggunakan Multimedia CD Interaktif lebih mengutamakan variasi teknik penyajian yang menarik yaitu 
dengan menggabungkan media audia, visual, dan animasi sehingga penyampaian informasi menarik dan memberikan kesempatan kepada mahasiswa untuk kreatif yang dapat berpengaruh positif dalam meningkatkan hasil belajar piano mahasiswa.

Perbedaan Hasil Belajar Piano Mahasiswa yang Memiliki Kecerdasan Musikal Tinggi dan Kecerdasan musikal Rendah

Hasil penelitian menunjukkan bahwa rata-rata hasil belajar piano yang memiliki kecerdasan musikal tinggi lebih tinggi daripada hasil belajar piano yang memiliki kecerdasan musikal rendah. Hal ini mengindikasi bahwa mahasiswa yang memiliki kecerdasan musikal tinggi lebih mampu memahami pelajaran piano dibandingkan siswa yang memiliki kecerdasan musikal rendah. Hal ini mengindikasikan bahwa mahasiswa yang memiliki kecerdasan musikal tinggi lebih mampu memahami pelajaran piano dibandingkan dengan mahasiswa yang memiliki kecerdasan musikal rendah. Mahasiswa yang memiliki kecerdasan musikal tinggi biasanya memiliki karakteristik berupa: (1) kemampuan membaca notasi musik, kemampuan menangkap nada, kemampuan mengikuti irama, kemampuan menciptakan musik, kemampuan mengaransemen lagu. Sedangkan mahasiswa yang memiliki kecerdasan musikal rendah memiliki karakteristik: 1) tidak mampu membaca notasi musik, (2) tidak bisa mengenali nada, 3) tidak mampu mengikuti irama musik.

Sebaliknya, kecerdasan musikal yang rendah akan berdampak pada buruknya tingkahlaku mahasiswa dalam belajar, mahasiswa akan merasa ragu untuk menyelesaikan tugas atau masalah belajarnya. Kecerdasan musikal yang tinggi membuat mahasiswa tersebut menjadi lebih semangat dalam mengikut pelajaran. Sedangkan mahasiswa yang memiliki keyakinan diri rendah, akan kurang kreatif dalam belajar.

Berdasarkan karakteristik kecerdasan musikal di atas, mahasiswa yang memiliki kecerdasan musikal tinngi akan memperoleh hasil belajar yang lebih tinggi daripada mahasiswa yang memiliki kecerdasan musikal rendah, khususnya dalam pembelajaran piano karena dalam pembelajaran piano dibutuhkan kesabaran, keuletan, kreativitas, motivasi, dan kegigihan dalam mengetahui teknologi yang baru beserta aplikasinya yang sangat berhubungan dalam kehidupan sehari-hari.

Seseorang dengan kecerdasan musikal rendah butuh banyak motivasi untuk belajar lebih banyak. Kecerdasan musikal yang rendah membentuk seseorang menjadi pribadi yang sulit berkonsentrasi pada tugas dan lebih fokus pada diri bukan pada tugas, takut gagal dan menganggap kegagalan adalah akibat dari ketidakmampuannya. Hal ini sering mengakibatkan perencanaan tugas menjadi lemah dan kesulitan menjadi lebih besar.

Berdasarkan pemaparan di atas dapat dipahami bahwa hasil belajar piano mahasiswa yang memiliki kecerdasan musikal lebih baik dari hasil belajar Piano mahasiswa yang memiliki kecerdasan musikal yang rendah.

Interaksi Multimedia $\mathrm{CD}$ Interaktif dan Kecerdasan musikal terhadap Hasil Belajar Piano

Temuan penelitian menunjukkan bahwa terdapat interaksi terdapat interaksi antara penggunaan Multimedia CD Interaktif dengan kecerdasan musikal terhadap hasil belajar piano. Mahasiswa yang memiliki kecerdasan musikal tinggi yang dibelajarkan dengan multimedia CD interaktif memperoleh hasil belajar piano yang lebih tinggi daripada mahasiswa yang memiliki kecerdasan musikal tinggi yang dibelajarkan dengan multimedia CD program. Dengan menggunakan Multimedia CD Interaktif proses terjadi lebih menarik karena melibatkan mahasiswa secara fisik dan mental. Dalam proses ini mahasiswa cenderung aktif menggunakan indera penglihatan dan indera pendengaran agar mamapu memproses serta memecahkan masalah yang dihadapi mahasiswa dan mendapat umpan balik secara langsung dari guru. Dengan menggunakan Multimedia CD Interaktif memberikan peluang yang lebih besar untuk meningkatkan ide imajinasi dan animasi yang dapat meningkatkan konsentrasi minat dan motivasi serta kemauan pada mahasiswa yang memiliki kecerdasan musikal tinggi. Demikian pula mahasiswa yang memiliki kecerdasan musikal rendah yang dibelajarkan dengan menggunakan multimedia CD interaktif memperoleh hasil belajar piano yang lebih rendah dibandingkan dengan mahasiswa yang dibelajarkan dengan menggunakan multimedia CD program. 
Multimedia interaktif merupakan multimedia pembelajaran yang menuntut adanya interaksi langsung dengan sumber informasi sehingga dapat meningkatkan rasa keingintahuan, minat, kreatifitas, motivasi belajar bagi mahasiswa yang memiliki kecerdasan musikal tinggi. Sejalan dengan itu bagi mahasiswa yang memiliki kecerdasan musikal tinggi akan terpacu untuk lebih giat belajar dan mampu mengendalikan diri karena mereka selalu optimis untuk dapat mengetahui informasi tentang tujuan penerapan piano dalam kehidupan sehari-hari dan meningkatkan hasil belajarnya. Sedangkan mahasiswa yang memiliki kecerdasan musikal rendah mungkin akan merasa khawatir dan was-was kalau mereka tidak mampu untuk mengikuti pembelajaran. Hal ini terjadi karena mahasiswa yang kecerdasan musikalnya rendah berdampak pada kurangnya motifasi belajar, kurangnya percaya diri akibat tidak mampu mengubah keadaan yang buruk. Mahasiswa yang memiliki kecerdasan musikal rendah juga kurang mampu mengendalikan diri sehingga dalam komunikasi dengan pengajar dalam pembelajaran tidak terjadi dengan baik yang berakibat dapat melunturkan semangat belajar mahasiswa jika dibelajarkan dengan menggunakan multimedia CD interaktif.

Multimedia CD Program merupakan pembelajaran yang berorientasi pada guru dengan materi yang disajikan dikemas dalam bntuk video yang bersifat linier sehingga lebih cocok bagi mahasiswa yang memiliki kecerdasan musikal rendah, hal ini disebabkan mahasiwa yang memiliki kecerdasan musikal rendah cenderung passif menunggu bimbingan dari guru. Dengan demikian guru memiliki banyak kesempatan untuk memberikan motivasi, semangat dan arahan sehingga mahasiswa lebih termotivasi dan terdorong dalam mengetahui dan memahami teknologi informasi dan komunikasi dalam kehidupan sehari-hari dan meningkatkan hasil belajarnya. Akan tetapi jika pembelajaran multimedia CD program diberikan kepada mahasiswa yang memiliki kecerdasan musikal tinggi akan menimbulkan kebosanan dan kejenuhan. Hal ini disebabkan proses pembelajaran terkesan monoton dan kurang memiliki variasi dalam penyajiannya serta pembelajaran kurang memberikan kesempatan kepada mahasiswa untuk aktif dan kreatif. Dengan demikian hasil belajar piano mahasiswa yang memiliki kecerdasan musikal rendah lebih tinggi dibandingkan dengan mahasiswa yang memiliki kecerdasan musikal tinggi jika dibelajarkan dengan menggunakan multimedia $\mathrm{CD}$ program. Dengan demikian pembelajaran multimedia CD interaktif lebih tepat diujisamakan kepada mahasiswa yang memiliki kecerdasan musikal tinggi dan pembelajaran dengan menggunakan multimedia CD program lebih tepat diberikan kepada mahasiswa yang memiliki kecerdasan musikal rendah.

\section{PENUTUP}

Simpulan hasil penelitian ini adalah sebagai berikut:

1. Hasil belajar piano mahasiswa yang menggunakan multimedia CD Interaktif lebih baik dibandingkan dengan multimedia CD Program. Dalam hal ini mahasiswa yang dibelajarkan dengan menggunakan multimedia CD Interaktif lebih baik dibandingkan dengan hasil belajar mahasiswa yang dibelajarkan dengan multimedia CD Program.

2. Hasil belajar mahasiswa yang memiliki kecerdasan musikal tinggi lebih baik dibandingkan dengan hasil belajar mahasiswa yang memiliki kecerdasan musikal rendah. Dengan demikian mahasiswa yang memiliki kecerdasan musikal tinggi memperoleh hasil belajar piano yang lebih baik dibandingkan dengan mahasiswa yang memiliki kecerdasan musikal rendah.

3. Terdapat interaksi antara multimedia pembelajaran dan kecerdasan musikal dalam mempengaruhi hasil belajar piano.

a. Hasil belajar piano mahasiswa yang memiliki kecerdasan musikal tinggi yang diajar menggunakan multimedia CD Interaktif lebih tinggi dibandingkan dengan hasil belajar piano mahasiswa yang memiliki kecerdasan musikal tinggi yang diajar dengan multimedia CD Program.

b. Hasil belajar piano mahasiswa yang memiliki kecerdasan musikal tinggi yang diajar menggunakan multimedia CD Interaktif lebih tinggi dibandingkan dengan hasil belajar piano mahasiswa yang memiliki kecerdasan musikal rendah yang diajar dengan multimedia CD Program. 
c. Hasil belajar piano mahasiswa yang memiliki kecerdasan musikal tinggi yang diajar menggunakan multimedia pembelajaran CD Interaktif lebih tinggi dibandingkan dengan hasil belajar piano mahasiswa yang memiliki kecerdasan musikal rendah yang diajar dengan multimedia CD Interaktif.

d. Hasil belajar piano mahasiswa yang memiliki kecerdasan musikal tinggi yang diajar menggunakan multimedia CD Program lebih tinggi dibandingkan dengan hasil belajar piano mahasiswa yang memiliki kecerdasan musikal rendah yang diajar dengan multimedia CD Program.

e. Hasil belajar piano mahasiswa yang memiliki kecerdasan musikal tinggi yang diajar menggunakan multimedia CD Program lebih tinggi dibandingkan dengan hasil belajar piano mahasiswa yang memiliki kecerdasan musikal rendah yang diajar dengan multimedia CD Interaktif.

f. Hasil belajar piano mahasiswa yang memiliki kecerdasan musikal rendah yang diajar menggunakan multimedia CD Interaktif lebih rendah dibandingkan dengan hasil belajar piano mahasiswa yang memiliki kecerdasan musikal rendah yang diajar dengan multimedia CD Program

\section{DAFTAR PUSTAKA}

Armstrong, T., 1996. Multiple Intelligences in The Classroom. Virginia : Association for Supervision and Curriculum Development.

Anastasi, A., Susana, U., 1997. Test Psikologi ( Psychological Testing, 7e) Edisi Bahasa Indonesia Jilid I, New York : Macmillan Publising Co, INC.

Arsyad, A., 2010. Media Pembelajaran. Jakarta : PT Raja Grafindo Persada

Ausubel, 1968. Educational Psychology : A Cognitive View. New York and Toronto: Holt, Rinehart and Winston.

Ary D., Jacobs L. C., dan Razavieh A., 1982. Pengantar Penelitian Dalam Pendidikan. Terjemahan Arief Furchan. Surabaya : Usaha Nasional

Banoe, P., 2003. Kamus Musik, Yogyakarta: Kanisius.
Bernstein, M. \& Picker, M., 1972. An Introduction to Music (4th. Ed., p. 1) NewJersey : Prentice Hall, Inc, Englewood Cliffs.

Booth,Victor, and Proff.Dungga,J.A.,1979. Bermain Piano Dengan Baik. Jakarta : $\mathrm{CV}$. Yasa Guna.

Brown, A.,dan Green,T.D., 2002. Multimedia Projects in The Classroom. California: Corwin Press, Inc

Budiningsih, C. A., 2005. Belajar dan Pembelajaran. Jakarta : PT. Rineka Cipta.

Campbell, Linda, Bruce Campbell dan Dee Dickinson. 2002. Teaching and Learning

Through Multiple Intelligences.

Casmini. 2007. Emotional Parenting. Yogyakarta : Pilar Media.

Darsono, Max, dkk.,2000. Belajar dan Pembelajaran, Semarang : IKIP Semarang Press

Daryanto. 2011. Media Pembelajaran. Bandung : PT. Satu Nusa.

Degeng, I.N.S., 1999. Rancangan Pembelajaran. Teori dan Teknik Pembelajaran. Malang : Universitas Kristen Cipta Wacana

Denes, A., 1998. Teaching Piano: a Comprehensive Guide and Reference Book for the Instructor. New York: Yorktown Music Press, Inc.

Dimyati dan Mudjiono, 2009. Belajar dan Pembelajaran, Jakarta: PT. Rineka Cipta.

Edmund K.P., 1996. Ilmu Bentuk Musik, Yogyakarta : Pusat Musik Liturgi

Effendi, A., 2005. Revolusi Kecerdasan Abad 21. Bandung: Alfabeta

Gagne,R.M., and Briggs, L.J., 1984. Principles of Instruction, ( $\left.2^{\text {nd }} E d\right)$, London : Scott, Foresman

Gardner, H., 1983. Multiple Intelligences (Kecerdasan Majemuk), Batam : Interaksara

Gora,W., 2005. Membuat CD Multimedia Interaktif Untuk Bahan Ajar E -Learning. Jakarta : PT Elex Media Komputindo.

Pembelajaran menurut Hadi Kusuma K. (1996: 15)

Hamdani, 2011. Strategi Belajar Mengajar, Pustaka Setia : Bandung.

Heinich, R. and Molenda, M. and Russel, D.J., 1985, Instructional media and The New Teclogies of Instruction, United State : John Willey \& Son. 
Indriana, D.,2011. Ragam Alat bantu Media Pengajaran, Yogyakarta : Diva press

Jamalus, 1988. Panduan Pengajaran Musik Melalui Pengalaman Musik, Jakarta : Departemen Pendidikan dan Kebudayaan

Kadir, A. dan Wahyuni,T., 2005. Pengenalan Teknologi Informasi, Yogyakarta : Andi

Kodijat, L., 1986. Tangga Nada dan Trinada. Jakarta : Djambatan

Kodijat, L., 2004. Iatilah-istilah Musik. Jakarta : Djambatan

Last, J.,1989. Pianis Remaja,Buku Pegangan Untuk Pengajar Dan Murid. Jakarta : Gramedia Pustaka Utama

Munir. 2010. Pembelajaran jarak jauh berbasis teknologi informasi dan Komunikasi. Bandung: Alfabeta

Muskibin,I.,2009. Kehebatan Musik Untuk mengasah Kecerdasan Anak, Jogjakarta : Power Books (Idhina).

Parekh, R.., 2006. Principles Of Multimedia, New Delhi : Tata-McGraw Hill

Piaget, J. 1817. Science Of Education and The Psychology of Child, New York : Wiley

Sadiman, A., dkk., 2003. Media Pendidikan : Pengertian, Pengembangan dan Pemanfaatan, Jakarta : Raja Grafindo persada

Sagala, S., 2009. Konsep dan Makna Pembelajaran. Bandung : CV. Alfabeta.

Schwier, R.A., \& Misanchuck, R.E., 1994. Instructional atechnology: The Difinition and Domains of the Field, Washington,DC : AECT

Soeharto, dkk. 1996. Kamus Musik. Jakarta: Mustika.

Sudjana, N., 2009. Penilaian Hasil Proses Belajar Mengaja. PT Remaja Rosdakarya: Bandung.

Sumadi, S., 1989. Psikologi Pendidikan. Jakarta : CV. Rajawali.

Warsita, B., 2008. Teknologi Pembelajaran Landasan dan Aplikasinya. Jakarta: Rineka Cipta.

Winkle,W.S., 2007. 